\title{
Energy, economic analysis and efficiencies of micro drip irrigation II- Economic Analysis and efficiencies
}

\author{
Mohamed E. El-Hagarey ${ }^{1}$,Mohammad N. El-Nesr ${ }^{1}$, Hani M. Mehanna ${ }^{2}$, \\ Hani A. Mansour ${ }^{2}$ \\ 1 Soil Conservation and Water Resources Dept., Desert Research Center, Egypt. \\ 2 Water Relations Field Irrigation Department, Agricultural and Biological Division, National Research \\ Center, Cairo, Egypt
}

\section{(1) Corresponding author,elhagarey@gmail.com}

Abstract: Research study was carried out for two successive seasons 2012 and 2013 on seven years old (Florda prince) peach trees (Purnus perseca L. Batsch) budded on Nemagard rootstock. The experiment was conducted at the experimental farm, modern reclamation lands, situated Bader City, South Al-Tahrir, AlBeharia Governate, Egypt.

Peach trees were planted at $5 \times 4 \mathrm{~m}$ in sandy soil, and were irrigated using four techniques of drip irrigation systems: Gr surfacr drip (SD) 4 l/h., Gr subsurface drip (SSD), surface micro drip (SMD) $0.5 \mathrm{l} / \mathrm{h}$, and subsurface micro drip(SSMD) under three amount of applied water (60,80,100\% of applied water will be called $T_{1}, T_{2}$ and $T_{3}$ ). Fourty two experimental trees were selected of normal growth with uniform of vigor. Statistical design was split with three replicets. And results show that,

The best irrigation water save is $20 \%$ for $T_{2}$ under all of SMD and SSMD irrigation system, on the other hand, $T_{1}$ under SMD irrigation system in all of first and second year is acceptance by irrigation water saving ratio $40 \%$, the high gradation for CWUE under various water amounts, $T_{1}$ water treatment is the higher value then $T_{2}$ and $T_{3}$ under various drip irrigation systems

The mean value of EEIS higher percentage in SSMD and SMD irrigation systems than its counterpart in SSD and SD irrigation system, beside at under all of SSMD irrigation systems is increasing with water amount increasing, The average energy production under SMD and SSMD irrigation systems is higher than SD and SSD irrigation systems by $18.8 \%$, cost of unit production unit (LE/kg) for SSMD and SMD irrigation systems are lower than SSD and SD irrigation systems by (32-38,3\%) at first season and (28,7-32\%) at second season approximately.

Keywords: micro-irrigation, drip irrigation water-save, peach trees,water use efficiency, peach quality yield, costs.

\section{Introduction}

Water resource management is the activity of planning, developing, distributing and managing the optimum use of water resources. It is a sub-set of water cycle management. Agriculture is the largest user of the world's freshwater resources, consuming 70 percent. As the world's population rises and consumes more food, industries and urban development's expand, and the emerging bio-fuel crops trade also demands a share of freshwater resources, water scarcity is becoming an important issue.

The main aims of research are energy, economic analysis and efficiencies of micro drip irrigation to determine the economic impact which related to dripper flow rate, and behavior of various irrigation efficiencies under various flow rates of drip irrigation systems.

(Mead, 2002) defined micro irrigation is usually 10 times less than common emitters. (Lubars, 2008) mention Advantages of this system are 1) Optimum growth conditions due to the ability to maintain, 2) optimum balance of air, water and nutrients in the soil, 3) Better utilization of available space, Plant density can be Increased, 4) Quicker turnaround of plant materials reducing growth cycles, 5) Higher yields, 6) Minimize leaching of nutrients that occurs with excess water Flow, 7) The micro rate system is much cheaper than the common micro-irrigation systems, smaller P.V.C. tubes size reduced horse power requirements, 8) No runoff on heavy soils, 9) No water loss through the root zone on very sandy soils, 10) Water and fertilizer saving up to $(40-50) \%$, 11) Better quality, and 12) Water could be applied efficiently on shallow soils in hilly areas.

Abdouet al, (2010) mention by comparing traditional trickle flow $8 \mathrm{~L} / \mathrm{h}$ and micro rate system $0.4 \mathrm{~L} / \mathrm{h}$ for the same water quantity 2.4 Liter, wetting pattern front for sand and clay soils at traditional trickle flow were faster than wetting pattern front at microirrigation system, which led to a significant loss in the amount of water by deep percolation in a short time, in traditional trickle flow the vertical wetting pattern fronts in sandy soil increase more than vertical in clay with $646.15 \%$, but the horizontal wetting pattern front in clay soil increase more than horizontal in sand with $8.8 \%$. 


\section{Matrials And Methods}

Research study was carried out for two successive seasons 2012 and 2013 on seven years old Florda prince peach trees (Purnus perseca L. Batsch) budded on Nemagard rootstock. The experiment was conducted at the experimental farm, modern reclamation lands, situated Bader City, south Al-Tahrir, Al-Beharia Governate, Egypt.

Peach trees (seven years) were planted at $5 \times 4 \mathrm{~m}$ in sandy soil, this investigation aimed to study the effect of irrigation using four techniques of drip irrigation systems: surface drip (SD) 4 1/h., Gr subsurface drip (SSD), surface micro drip (SMD) $0.51 / \mathrm{h}$, and subsurface micro drip (SSMD) under three amounts of applied water $\left(60,80,100 \%\right.$ of calculated applied water called $T_{1}, T_{2}$ and $\left.T_{3}\right)$ on yield, fruit quality and some leaf parameters peach trees.

\section{Fertilization program:}

For peach trees, amounts of fertilizers are applied according to the recommendations of Field Crop Institute, ARC, Egypt, Ministry of Agricultural and Land Reclamation for Peaches trees .

\section{Irrigation system:}

The irrigation system consisted of the following components:

\section{a- Control head:}

Control head consisted of centrifugal pump $5 / 5$ inches $(20 \mathrm{~m}$ lift and $80 \mathrm{~m} 3 / \mathrm{h}$ discharge), driven by diesel engine (50 Hp), Control head consisted of centrifugal pump 5/5 inches $(20 \mathrm{~m}$ lift and $80 \mathrm{~m} 3 / \mathrm{h}$ discharge), driven by diesel engine ( $50 \mathrm{Hp}$ ), pressure gauges, control valves, inflow gauges, water source in the form of an aquifer, main line then lateral lines and dripper lines. For traditional drip irrigation, Gr dripper $(4 \mathrm{l} / \mathrm{h} / \mathrm{m}$ discharge, two dripper at one meter) was used, every trees row has two hoses and the one tree was $64 \mathrm{l} / \mathrm{h}$. tree, where micro drip irrigation was one hose for every tree row, total discharge, and one dripper $81 / \mathrm{h}$. tree with 4 cross four distributor to result 21/h., a (Fig., 1), in drip irrigation systems, the total dripper discharge for one tree was $641 / h$ ( 16 dripper X $41 / h$ ) while for micro drip irrigation systems, the tree discharge was $81 / h$ ( 4 distributor X $21 / h)$.

\section{Irrigation requirements:}

Irrigation water requirements for peach trees were calculated according to the local weather station data at Al-Beharia Governorate, belonged to the Central Laboratory for Agricultural Climate (C.L.A.C.), Ministry of Agriculture and Land Reclamation.

Irrigation process was done by calculated crop consumptive use ( $\mathrm{mm} /$ day) according to Doorenbos and Pruitt(1977).

Water requirements for Peach trees were calculated according to the following equation as recommended by Keller and Karmeli (1975). Table (1) and table (2).

$$
\begin{array}{ll} 
& I R=\left[\frac{K_{c} \times E t_{o} \times A \times C_{F}}{10^{7} \times E a}\right] \\
\text { Where: } & =\text { Irrigation water requirements, } \mathrm{m}^{3} / \mathrm{ha} / \text { day. } \\
\mathbf{I R} & =\text { Potential evapo-transpiration, } \mathrm{mm} \mathrm{day}{ }^{-1} \\
\mathbf{E} \mathbf{t}_{\mathbf{o}} & =\text { Crop factor of peach, } \\
\mathbf{K c} & =\text { Area irrigated, }\left(\mathrm{m}^{2}\right) \\
\mathbf{A} & =\text { Application efficiency, } \%, \text { where } 90 \% \text { drip irrigation. } \\
\mathbf{E a} & =\text { Leaching requirements. } \\
\mathbf{L R} & =\text { Covering factor, for peach trees } 45 \% .
\end{array}
$$

\begin{tabular}{|c|c|c|c|c|c|c|}
\hline Growth stage & month & $\begin{array}{l}\mathbf{E T}_{\mathbf{o}} \\
\mathrm{mm} / \mathrm{day}\end{array}$ & $\mathbf{K}_{\mathbf{c}}$ & $\begin{array}{l}\mathrm{Et}_{\mathrm{c}} \\
\mathrm{mm} / \mathrm{day}\end{array}$ & $\begin{array}{l}I_{\mathbf{t}}(\mathrm{L} / \text { tree/ } \\
\text { day) }\end{array}$ & $\begin{array}{l}I_{d}\left(m^{3} / h a /\right. \\
\text { day })\end{array}$ \\
\hline \multirow{3}{*}{ Initial } & January & 2.4 & 0.48 & 1.152 & 11.5 & 5.78 \\
\hline & February & 3.2 & 0.48 & 1.536 & 15.4 & 7.72 \\
\hline & march & 4.2 & 0.48 & 2.016 & 20.2 & 10.11 \\
\hline \multirow{4}{*}{ Mid-season } & April & 5.6 & 0.79 & 4.424 & 44.2 & 22.20 \\
\hline & May & 6.6 & 0.79 & 5.214 & 52.1 & 26.17 \\
\hline & June & 7.3 & 0.79 & 5.767 & 57.7 & 28.94 \\
\hline & July & 7.2 & 0.79 & 5.688 & 56.9 & 28.54 \\
\hline \multirow[t]{2}{*}{ Season end } & Augusts & 6.7 & 0.75 & 5.025 & 50.3 & 25.21 \\
\hline & September & 5.6 & 0.75 & 4.2 & 42.0 & 21.08 \\
\hline Total $\left(\mathbf{I}_{\mathrm{y}}\right)$ & \multicolumn{6}{|c|}{$5781.44\left(\mathrm{~m}^{3} /\right.$ ha/season $)$. } \\
\hline
\end{tabular}

Crop factor of peach was used to calculate Et $t_{\text {crop }}$ values, according to FAO,(1984).

Table (1): Calculated consumptive use ( $\mathrm{mm} /$ day) of peach trees. 
Energy, economic analysis and efficiencies of micro drip irrigation II- Economic Analysis ....

Where:

$\mathbf{I}_{\mathbf{t}}=$ Irrigation requirements for tree per day $(\mathrm{L} / \mathrm{ha} /$ day $)$

$\mathbf{I}_{\mathbf{d}}=$ Irrigation requirements for ha per day $\left(\mathrm{m}^{3} / \mathrm{ha} /\right.$ day $)$,

$\mathbf{I}_{\mathbf{y}}=$ Irrigation requirements for ha per season $\left(\mathrm{m}^{3} / \mathrm{ha} /\right.$ season $)$.

Table (2): Calculated water amounts versus irrigation systems for peach trees. Characters Irrigation requirements per season for hectare $\left(\mathrm{m}^{3} / \mathrm{ha} / \mathrm{season}\right)$

\begin{tabular}{ll}
\hline $\mathbf{6 0} \%$ ETC $=\left(\mathbf{T}_{1}\right)$ & 3468.86 \\
\hline $\mathbf{8 0} \%$ ETC $=\left(\mathbf{T}_{2}\right)$ & 4625.15 \\
\hline $\mathbf{1 0 0 \%}$ ETC $=\left(\mathbf{T}_{3}\right)$ & 5781.44 \\
\hline
\end{tabular}

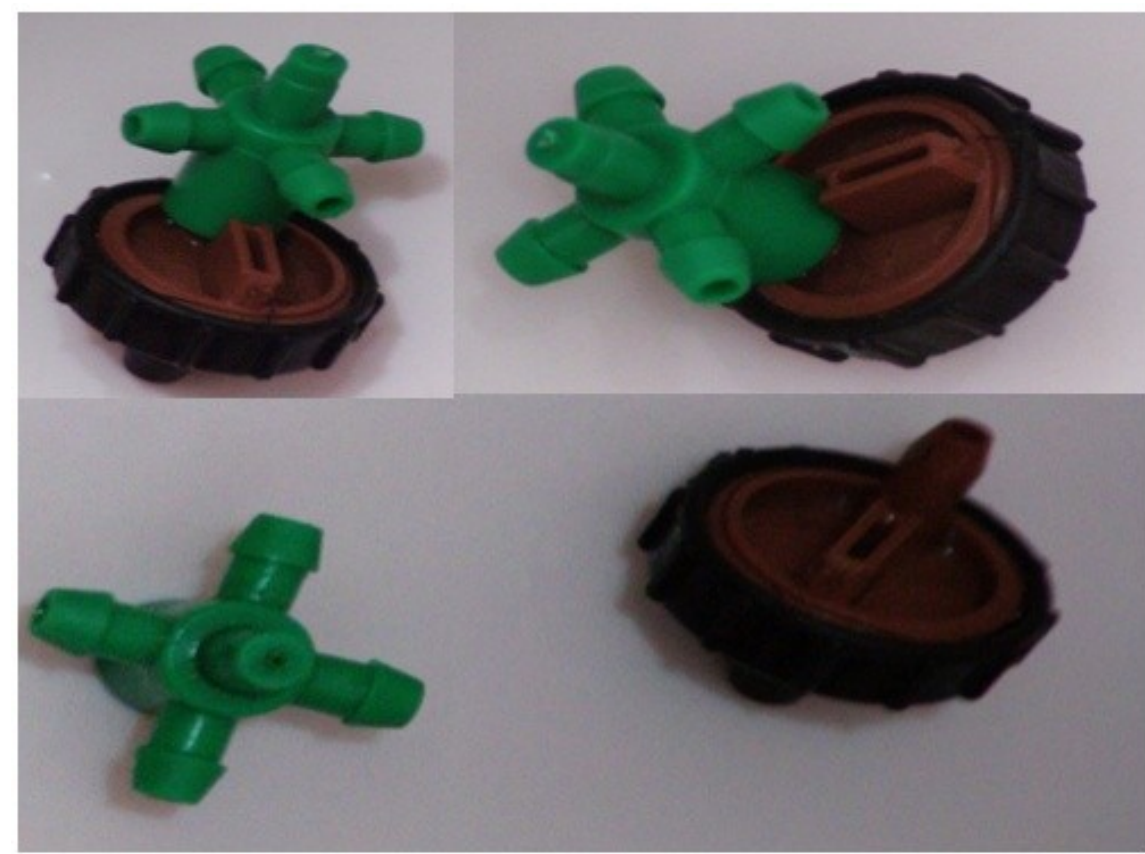

Fig. (1).Micro drip irrigation dripper, $2 \mathrm{l} / \mathrm{h}$ but every dripper have a cross four distributor toresult $0.5 \mathrm{l} / \mathrm{h}$.

\section{Measurements and calculations:}

-Storage water efficiency(SE):

Storage water efficiency (SE)is the ratio of the volume of irrigation water that is beneficially used to the total volume of irrigation water applied expressed as percent, ASCE (I978):

$$
\mathrm{SE}=\frac{\text { averagedepthofwaterbeneficiallyused }}{\text { averagedepthofappliedwater }} \times 100
$$

\section{- Irrigation water saving percentage}

Water saving was estimated acoording to following equation

Water saving $=\left(\mathrm{I}_{\mathrm{f}}-\mathrm{I}_{\mathrm{n}}\right) / \mathrm{I}_{\mathrm{f}} \times 100$

Where:

$$
\begin{aligned}
& \mathbf{I}_{\mathbf{f}}=\text { Water use for control treatment }\left(\mathrm{m}^{3} / \mathrm{fed}\right) \text {, and } \\
& \mathbf{I}_{\mathbf{n}}=\text { Water use for various treatment }\left(\mathrm{m}^{3} / \mathrm{fed}\right) .
\end{aligned}
$$

\section{Water use efficiency (CWUE, $\left.\mathrm{kg} / \mathrm{m}^{3}\right)$.}

This efficiency defined as the yield / ET ratio. In practice irrigation water use efficiency would be more conveniently expressed as mass of marketable crop per unit volume of water $\left(\mathrm{kg} / \mathrm{m}^{3}\right)$ as it has been done by many others over the past two decades, Burman er at. (1983).

Crop water use efficiency $=$ [grain yield / crop water consumption]

- $\quad$ Unit production cost (LE/kg).

- $\quad$ Economical efficiency of irrigation systems (EEIS)(\%).

$$
\text { Uniteproduction } \cos t=\frac{\text { Annual irrigation cost }(\mathrm{LE} / \mathrm{m} 3)}{\mathrm{WUE}(\mathrm{kg} / \mathrm{m} 3)}
$$

EEIS $=($ Actual yield per fed/ typical yield per ha $)$ 


\section{Cost analysis:}

Cost analysis to evaluate micro drip irrigation systems comparing with trdtional drip irrigation systems, cost analysis was computed according to Worth and Xin (1983), Fixed and operation cost is calculated according to market price level of 2012 for equipment and operating irrigation process, and for drip irrigation systems, Cost analysis is based on one Feddan.

Fixed cost is calculated according to market price level of 2006 for equipment and operating irrigation process, and for miut irrigation and drip irrigation irrigation pipes, price of PVC line according to market prices2012. Cost analysis is based on 50 feddan.

\section{1- Initial cost (IC) :}

$(\mathbf{I C})(\mathbf{L E} / \mathbf{h a})=$. micro and drip irigation system price $(\mathbf{L E}) \times$ Item quantity per Ha

\section{2- Annual fixed cost (F):}

Annual fixed cost (LE/year) invested in the irrigation system was calculated according to the following equation:

Where:

$$
\mathbf{F}=\mathbf{D}+\mathbf{I}+\mathbf{T}
$$

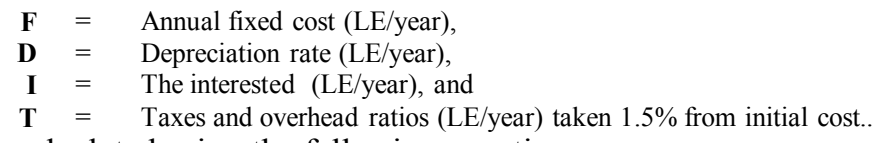

Depreciation rate cost was calculated using the following equation :

$$
\begin{gathered}
\mathbf{D}=(\text { I.C - D.C }) / \text { E.L } \\
I=(\text { I.C }+ \text { D.C }) \times 0.5 I R
\end{gathered}
$$

Interest on initial was calculated as follows:

Where :

$$
\begin{aligned}
\text { I.C } & =\text { Initial cost (LE/ha), } \\
\text { D.C } & =\text { Price after depreciation (LE), } \\
\text { E.L } & =\text { Expected life (year), and } \\
\text { IR } & =\text { Interest rate per year (taken } 14 \%) .
\end{aligned}
$$

Taxes and overhead ratios were taken as $1.5 \%$ of initial cost.

- Capital recovery factor $(\mathrm{CRF})=$ depreciation + interest on investment:

Where :

$$
\mathrm{CRF}=\frac{\mathbf{i}(\mathbf{1}+\mathbf{i})^{\mathrm{n}}}{(\mathbf{1}+\mathbf{i})^{\mathrm{n}}}-\mathbf{1}
$$

Equipment costs per year $=\mathrm{CRF} \times$ intial cost.

$$
\begin{aligned}
\mathbf{C R F} & =\text { Capital recovery factor, } \\
\mathbf{i} & =\text { The interest rate decimal, and } \\
\mathbf{n} & =\text { The period of analysis. }
\end{aligned}
$$

3- Operating cost $(\mathbf{O})$ :

Annual operating cost (LE/year) of the capital investment in the irrigation system was calculated as follows:

Where:

$$
\mathbf{O}=\mathbf{L}+\mathbf{E}+(\mathbf{R} \& \mathbf{M})+\mathbf{I S}
$$

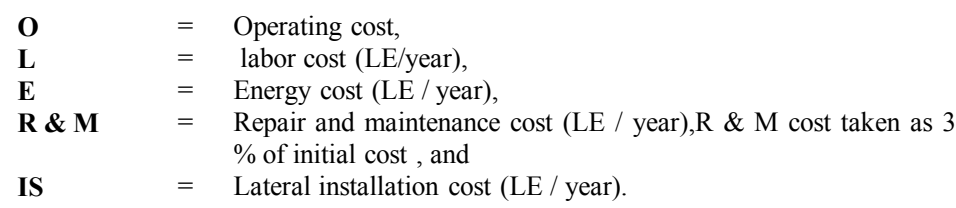

Labor cost was calculated based on one man for irigation systems.

Energy cost was calculated as follows:

Where:

$$
\mathbf{B p}=\frac{\mathbf{Q} \cdot \mathbf{T D H}}{\mathbf{k} \cdot \mathbf{E}}
$$

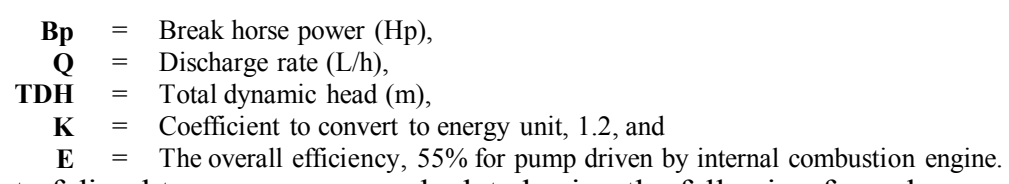

The power cost of diesel type source was calculated using the following formula:

Where:

$$
\text { E.C }=1.2 \text { Bp H } * S * \text { F.C }
$$

$$
\begin{array}{ll}
\mathbf{E . C} & =\text { Energy cost of diesel }(\mathrm{LE} / \mathrm{Hp}), \\
\mathbf{H} & =\text { Annual operating hours }(\mathrm{h}), \\
\mathbf{S} & =\text { Specific fuel consumption }(\mathrm{L} / \mathrm{Hp} . \mathrm{h}),
\end{array}
$$


F.C $=$ Fuel price (LE), and

$\mathbf{1 . 2}=$ Factor accounting for lubrication

4-Total annual cost $(\mathrm{LE} / \mathrm{year})=\mathrm{F}+\mathrm{O}$

5- Unit production irrigation cost $(\mathrm{LE} / \mathrm{kg})=$

$\left[\frac{\text { Annual irrigation cost }\left(\mathrm{LE} / \mathrm{m}^{3}\right)}{\text { FWUE }\left(\mathrm{kg} / \mathrm{m}^{3}\right)}\right]$

III. Results and Discussions

\section{- Water storage efficiency (SE\%):}

It's appear that, the storgae efficiency percentage of SSMD is the highest percentage then SMD ten SSD and finally in the last SD irrigation system, as result to saving water from losses by deep percolation in sandy soil beside reduce the evaproation losses, therefor the actual water amount stored in the effective root zone in SSMD and SMD irrigation system was be higher more than it's counterpart in SSD and SD drip irrigation systems.Fig. (2)

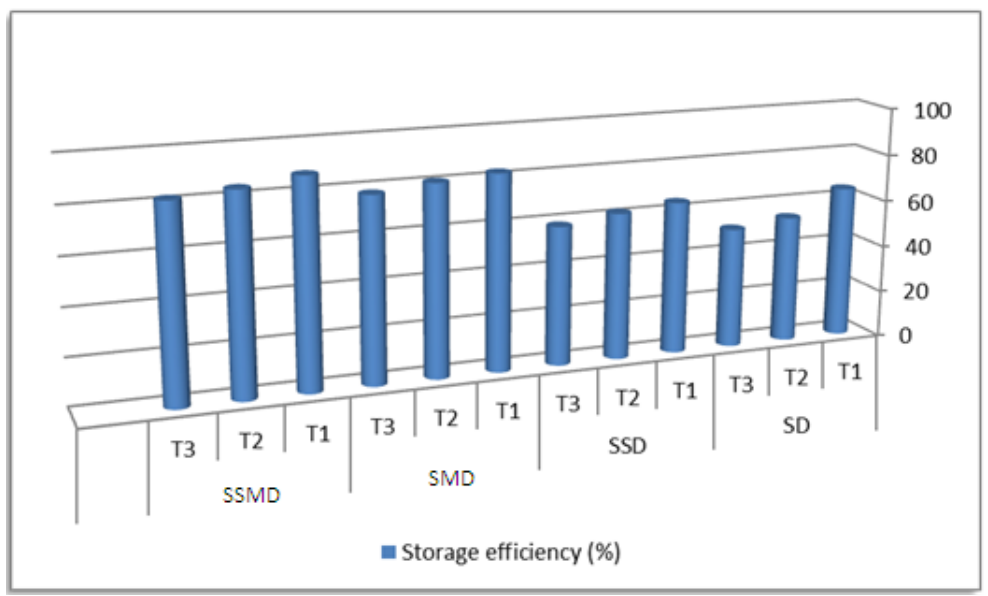

Fig. (2). Storage efficiency (\%), for water applied treatments, under SSMD, SMD, SSD and SD irrigation system.

\section{- Irrigation water saving percentage:}

During the first season, the highest yield was gained using T2 and T3 water under SMD irrigation system, so the SMD irrigation system saved $20 \%$ of the applied irrigation water using T2 water treatment, while in the second season, The interaction between the two studied factors, provided that using T3 under SSD, and T2 and T3 under SSMD had the highest significant values. So the best irrigation water saving is $20 \%$ was obtained using T2 under SMD and SSMD irrigation systems.

\section{- Crop water use efficiency (CWUE) $\left(\mathrm{kg} / \mathrm{m}^{3}\right)$.}

It's clear that the high gradation for CWUE under various water amounts, $\mathrm{T}_{1}$ water treatment is the higher value then $T_{2}$ and $T_{3}$ under various drip irrigation systems according to the used water amount in $T 1$ is more saving water by $40 \%$ then T2 by $20 \%$ specially at SSMD and SMD the difference is clear with comparing to SD and SSD drip irrigation systems, the difference refers to save water and nutrients losses by deeppercolation and evaporation, according to (Lubars, 2008), and allowing of opportunity for plant at more time to absorb nutrients and water beside have a good environment to process of photosynthesis and respiration Which reflects positively on the amount of crop. Fig.(3). 


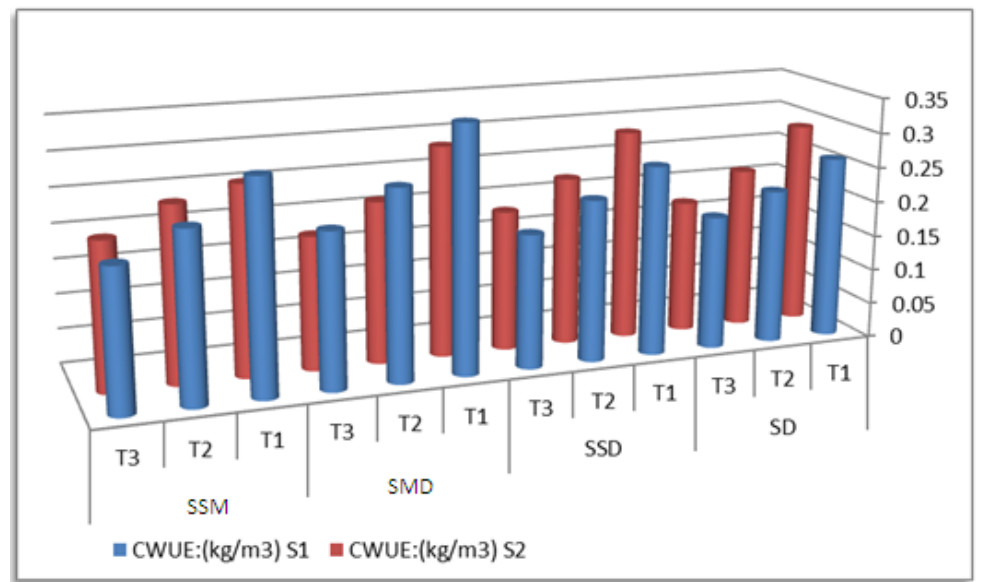

Fig. (3)Crop water use efficienc y $\left(\mathrm{kg} / \mathrm{m}^{3}\right)$, for water applied treatments, under SSMD,

SMD, SSD and SD irrigation system.

Unit production irrigation cost ( $\mathrm{LE} / \mathrm{kg})$.

Irrigation cost for peach production unit was an economical and important impact factor for farmers and agricultural investors, it considers about the irrigation cost of weight unit of peaches, regards to illustrated data in Table (3), irrigation cost of peaches production unit under SSD and SD irrigation systems was doubled comparing with under SSMD and SMD, and these results due to capital and the low annual fixed costs of SSMD and SMD irrigation systems which was approximately half comparing with SSD and SD irrigation costs, because the differences of pipes size for SSMD and SMD irrigation systems according to water amount flow (Fig. ,4).

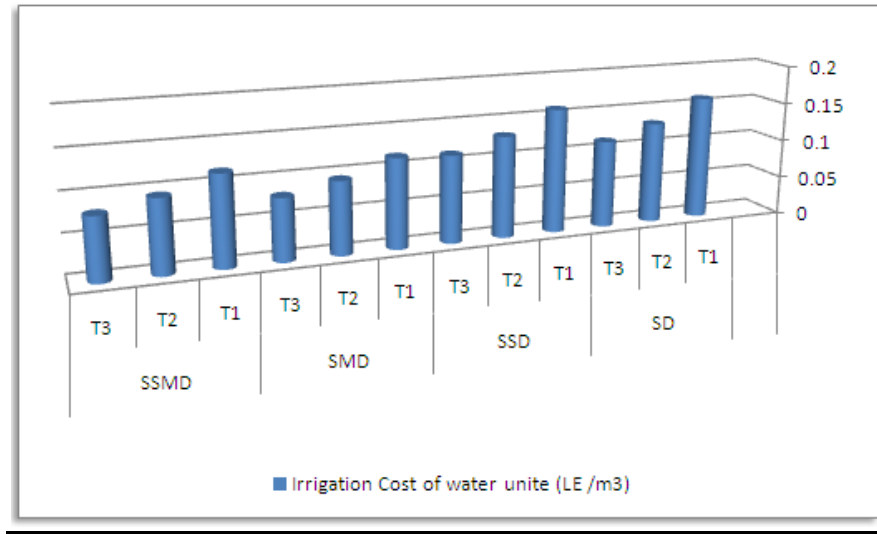

Fig. (4) Irrigation Cost of water unite, $\left(\mathrm{LE} / \mathrm{m}^{3}\right)$, for water applied treatments, under SSMD, SMD, SSD and SD irrigation system.

\section{Economical efficiency of irrigation systems (EEIS) (\%).}

Economical irrigation efficiency is an important engineering term that involves understanding soil and agronomic sciences to achieve the greatest benefit from irrigation process. The enhanced understanding of irrigation efficiency can improve the beneficial use of limited and declining water resources needed to increase and improve crop and food production from irrigated lands.

Economical efficiency of irrigation systems is the ratio between actual yield of various water treatments under the studied irrigation systems per fed, the highest EEIS percentage achieved under SSMD irrigation system and T3 water treatment at the first seasone. Generally, the highest values of EEIS were uner SSMD and SMD irrigation systems followed by SSD and SD irrigation systems

\section{- Cost analysis:}

By calculating both annual fixed and operating costs for SSMD, SMD, SSD and SD irrigation systems, it was clear that SSMD and SMD irrigation systems were more economical than SD and SSD irrigation systems. This difference was due to the increase of capital and annual fixed costs for SSD and SD irrigation systems, moreover low operating costs due to reducing of repairs and maintenance costs according to less hoses and pipes costs, the reduction of energy requirements. Data in Table (4) show that the capital and annual fixed costs for SSMD and SMD irrigation systems were lower than for SSD and SD irrigation systems by $25 \%$, so the cost of 
one $\mathrm{m} 3$ of water in LE for SSMD and SMD irrigation systems were lower than SSD and SD irrigation systems by $27 \%-30 \%$. Finally, the cost of production unit (LE/kg) for SSMD and SMD irrigation systems was lower than under SSD and SD irrigation systems by $32 \%$ and $38.3 \%$ in the first season and by 28.7 and $32 \%$ in the second season, respectively (Table, 3, and Fig., 4 and 5).

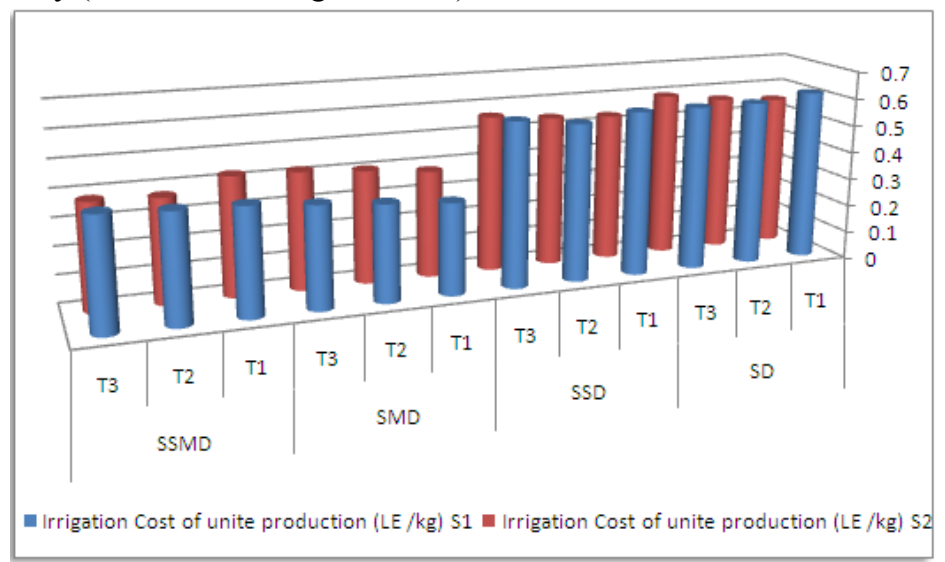

Fig. (5) Irrigation Cost of unite production, (LE / $\mathrm{kg}$ ), for water applied treatments, under SSMD, SMD, SSD and SD irrigation system.

\section{Conclusion}

Cost of SD and SSD irrigation systems was higher than SMD and SSMD irrigation systems, for that SSMD and SMD irrigation system were more economical compared with SD and SSD irrigation systems, Irrigation cost of production unit under SMD and SSMD irrigation system for the different water treatments was lower than under SD and SSD irrigation systems for the experimental water treatments, it was doubled under SSD and SD irrigation systems comparing with SSMD and SMD.

Table (3): Cost analysis for surface drip, subsurface drip, surface micro drip and subsurface micro drip.

\begin{tabular}{|c|c|c|c|c|c|c|c|c|c|c|c|c|}
\hline \multirow{2}{*}{$\begin{array}{l}\text { Irrigation systems } \\
\text { Water treatments }\end{array}$} & \multicolumn{3}{|c|}{ SD } & \multicolumn{3}{|c|}{ SSD } & \multicolumn{3}{|c|}{ SMD } & \multicolumn{3}{|c|}{ SSMD } \\
\hline & $T_{1}$ & $\mathrm{~T}_{2}$ & $\mathrm{~T}_{3}$ & $\mathrm{~T}_{1}$ & $\mathrm{~T}_{2}$ & $\mathrm{~T}_{3}$ & $\mathrm{~T}_{1}$ & $\mathrm{~T}_{2}$ & $\mathrm{~T}_{3}$ & $\mathrm{~T}_{1}$ & $\mathrm{~T}_{2}$ & $\mathrm{~T}_{3}$ \\
\hline \multicolumn{13}{|c|}{ 1- Capital cost, LE/ha } \\
\hline Control head, LE/Ha & \multicolumn{6}{|c|}{10353} & \multicolumn{6}{|c|}{10353} \\
\hline Drip net cost, LE/Ha & \multicolumn{6}{|c|}{5840.83} & \multicolumn{6}{|c|}{2870} \\
\hline Hose emitters cost, LE/ha & \multicolumn{6}{|c|}{3198.72} & \multicolumn{6}{|c|}{1249.5} \\
\hline Subtotal & \multicolumn{6}{|c|}{19393} & \multicolumn{6}{|c|}{14472} \\
\hline \multicolumn{13}{|c|}{2 - Annual fixed cost, LE/year } \\
\hline Deprecation & \multicolumn{6}{|c|}{1454} & \multicolumn{6}{|c|}{1085} \\
\hline Interest & \multicolumn{6}{|c|}{1697} & \multicolumn{6}{|c|}{1266} \\
\hline Taxes and Insurance & \multicolumn{6}{|c|}{291} & \multicolumn{6}{|c|}{217} \\
\hline Subtotal & \multicolumn{6}{|c|}{3442} & \multicolumn{6}{|c|}{2569} \\
\hline \multicolumn{13}{|c|}{ 3-Annual operating costs, LE/ha } \\
\hline Labor & \multicolumn{6}{|c|}{86} & \multicolumn{6}{|c|}{38} \\
\hline Energy & 1432 & 1908 & 2385 & 1431 & 1908 & 2385 & 954 & 1272 & 1590 & 954 & 1272 & 1590 \\
\hline
\end{tabular}


Energy, economic analysis and efficiencies of micro drip irrigation II- Economic Analysis ....

\begin{tabular}{|c|c|c|c|c|c|c|c|c|c|c|c|c|c|}
\hline \multirow{2}{*}{\multicolumn{2}{|c|}{$\begin{array}{l}\text { Repairs and maintenance } \\
\text { Subtotal }\end{array}$}} & \multicolumn{6}{|c|}{582} & \multicolumn{6}{|c|}{434} \\
\hline & & 2100 & 1908 & 2385 & 1431 & 1908 & 2385 & 1426 & 1272 & 1590 & 954 & 1272 & 1590 \\
\hline \multicolumn{2}{|c|}{ Annual Total Costs, LE/ha/season } & 24934 & 1908 & 2385 & 1431 & 1908 & 2385 & 18467 & 1272 & 1590 & 954 & 1272 & 1590 \\
\hline \multicolumn{2}{|c|}{$\begin{array}{l}\text { Irrigation Cost of water unite, LE } \\
/ \mathrm{m}^{3}\end{array}$} & 0.16 & 0.131 & 0.113 & 0.16 & 0.131 & 0.113 & 0.116 & 0.094 & 0.08 & 0.116 & 0.094 & 0.08 \\
\hline \multirow{2}{*}{$\begin{array}{l}\text { Irrigation Cost of unite } \\
\text { production (LE } / \mathrm{kg} \text { ) }\end{array}$} & $s_{1}$ & 0.617 & 0.594 & 0.594 & 0.594 & 0.568 & 0.594 & 0.33 & 0.347 & 0.366 & 0.385 & 0.39 & 0.402 \\
\hline & $s_{2}$ & 0.553 & 0.568 & 0.594 & 0.535 & 0.544 & 0.564 & 0.385 & 0.407 & 0.423 & 0.428 & 0.375 & 0.383 \\
\hline \multicolumn{2}{|l|}{ Irrigation systems } & \multicolumn{3}{|c|}{ SD } & \multicolumn{3}{|c|}{ SSD } & \multicolumn{3}{|c|}{ SMD } & \multicolumn{3}{|c|}{ SSMD } \\
\hline \multicolumn{2}{|l|}{ Water treatments } & $\mathrm{T}_{1}$ & $\mathrm{~T}_{2}$ & $\mathrm{~T}_{3}$ & $\mathrm{~T}_{1}$ & $\mathrm{~T}_{2}$ & $\mathrm{~T}_{3}$ & $\mathrm{~T}_{1}$ & $\mathrm{~T}_{2}$ & $\mathrm{~T}_{3}$ & $\mathrm{~T}_{1}$ & $\mathrm{~T}_{2}$ & $\mathrm{~T}_{3}$ \\
\hline \multicolumn{14}{|c|}{ l-Capital cost, LE/ha } \\
\hline \multicolumn{2}{|l|}{ Control head, $\mathrm{LE} / \mathrm{Ha}$} & \multicolumn{6}{|c|}{4350} & \multicolumn{6}{|c|}{4350} \\
\hline \multicolumn{2}{|l|}{ Drip net cost, $\mathrm{LE} / \mathrm{Ha}$} & \multicolumn{6}{|c|}{2454.13} & \multicolumn{6}{|c|}{1205.7} \\
\hline \multicolumn{2}{|l|}{ Hose emitters cost, LE/ha } & \multicolumn{6}{|c|}{1344} & \multicolumn{6}{|c|}{525} \\
\hline \multicolumn{2}{|l|}{ Subtotal } & \multicolumn{6}{|c|}{8148.3} & \multicolumn{6}{|c|}{6080.7} \\
\hline \multicolumn{14}{|c|}{2 - Annual fixed cost, LE/year } \\
\hline \multicolumn{2}{|l|}{ Deprecation } & \multicolumn{6}{|c|}{611.1} & \multicolumn{6}{|c|}{456} \\
\hline \multicolumn{2}{|l|}{ Interest } & \multicolumn{6}{|c|}{712.9763} & \multicolumn{6}{|c|}{532.0613} \\
\hline
\end{tabular}

\section{References}

[1]. AbdouS. H,Hegazi, El-Gindy, A. M. and Sorlini, C.(2010). M. M, Performance of Ultra-Low Rate of Trickle Irrigation. Misr J. Ag. Eng., Irrigation and drainage, 27 (2): 549- 564.

[2]. Doorenobs, J. and W.O. Pruitt (1977).Guidelines for predicting crop water requirements .FAO Irrigation. and Drainage. Paper 24.Rome, Italy: p 156.

[3]. Elmesery. A. A. M. (2010). Water movement in soil under misro trickle irrigation system.Misr J. Ag. Eng., Irrigation and drainage, 28 (3): 590- 612

[4]. FAO (1984).Guidelines for predicting crop water requirements. FAO Irrigation and Drainage paper No.24

[5]. Gilead,G.(2012) (http://www.trickle-l.com/new/archives/uldi.html

[6]. Keller, J. and D. Karmeli (1975). Trickle irrigation design rain bird sprinkler manufacturing crop. GlendorCalfi, 91740 USA: $24-26$

[7]. Lubars, P. (2008) http://www.scribd.com/doc/8145273/p13

[8]. Mead, R. (2002)http://www.americanfarm.com/signe\%2010-01.htm1

[9]. Worth,B. and J. Xin (1983).Farmmechanization for profit. Granada Publishing.UK.pp.250- 269. 